DOI: 10.17707/AgricultForest.63.4.03

\author{
Alexandra D. SOLOMOU, \\ Elpiniki SKOUFOGIANNI and Faik KAMPERLLARI
}

\title{
PATTERNS OF HERBACEOUS PLANT SPECIES RICHNESS, COMPOSITION AND SOIL PROPERTIES IN AN ORGANIC CULTIVATION "LEMON VERBENA" AND ABANDONED AGROECOSYSTEMS OF GREECE
}

\begin{abstract}
SUMMARY
Aromatic plants constitute a major segment of the flora, which provides raw materials for use in the pharmaceuticals, cosmetics, and drug industries. Lemon verbena is one of more than 30 species of aromatic shrubs in the genus Aloysia (family Verbenaceae) with high environmental and economic value. More attention is paid in Greece to the Lemon verbena essential oil while their effects on the parameters influencing multiple aspects of ecosystem structure (e.g. biodiversity, soil properties etc) are generally overlooked. Hence, this exploratory study aims to evaluate the effects of Lemon verbena and neighboring abandoned (10 years) ecosystems on the herbaceous plant species richness and composition, and soil properties. Also, the multiple regression method was used to investigate the relationship between herbaceous plant species richness and soil properties. The study was conducted in April-May 2016 and 2017 of central Greece. In total, 24 species of herbaceous plants (16 plant species in Lemon verbena ecosystem and 12 plant species in abandoned ecosystem) were recorded in the study area. The most frequently occurring plant was Avena sterilis (Family: Poaceae) in both types of ecosystems. Moreover, there were significant differences $(\mathrm{p}<0.05)$ between Lemon verbena and neighboring abandoned $(10$ years) ecosystems for any of the soil properties [soil organic matter, $\mathrm{pH}, \mathrm{CaCO}_{3}$, $\mathrm{P}, \mathrm{K}$ and $\mathrm{Mg}$ ] measured. Furthermore, multiple regression method showed that soil properties had significant effects on herbaceous plant species richness in which soil organic matter, $\mathrm{pH}, \mathrm{P}$ and $\mathrm{K}$ were the most prominent factors influencing species richness in Lemon verbena ecosystem.
\end{abstract}

Keywords: Aromatic Plant, Species Richness, Environment, Sustainability, Greece.

\footnotetext{
${ }^{1}$ Alexandra D. Solomou (corresponding author: alexansolomou@gmail.com) Laboratory of Forest Ecology, Institute of Mediterranean Forest Ecosystems, Hellenic Agricultural Organization "Demeter", GREECE; Elpiniki Skoufogianni, Faik Kamperllari, Laboratory of Agronomy and Applied Crop Physiology, Department of Agriculture, Crop Production and Rural Environment, University of Thessaly, Volos, GREECE.

Paper presented at the 8th International Scientific Agricultural Symposium "AGROSYM 2017".

Notes: The authors declare that they have no conflicts of interest. Authorship Form signed online.
} 


\section{INTRODUCTION}

Greece is considered as one of the most biologically diverse countries of the European continent with high plant diversity and endemism. Greece holds $6 \%$ of the Mediterranean area and $26 \%$ of the Mediterranean flora. Aromatic and medicinal plants are important factors in sustainable development, environmental protection and public health (Solomou et al., 2016).

One of the most important aromatic plants is Lemon verbena (Aloysia triphylla [L'Hurit.]) with important health benefits and ecosystem services. More specifically, Lemon verbena, is indigenous to South America (Duarte et al., 2007) and brought to Europe by the Spaniards and now is cultivated in many countries in Latin and Central America,in Southern Europe (Greece, France), in Northern Africa (Algeria, Morocco) China, and Iran. It is used as both a cullinary and a medicinal herb. The genus Alloysia belongs to the Verbenaceae family which has many genus and species. Lemon verbenas' botanical synonyms include Aloysia citriodora, Aloysia sleumeri Moldenke, Aloysia triphylla(L'Hur.) Britton, Lippia citriodora (Lam.) Kunth, Lippia triphylla(L'Hur.) Kuntze, Verbena citriodora Cav., Verbena triphylla, and Zapania citriodora Lam. (Zamorano-Ponce, 2004). It is a medicinal and aromatic shrub about $0.5-2 \mathrm{~m}$ in height. It is an evergreen perennial plant, a deciduous sub-shrub, and the genus Alloysia comprises about 175 genera and 2,300 species. It likes warm moist conditions with plenty of sunlight. When exposed to frost, it becomes deciduous. Lemon verbena prefers light, sandy, medium loamy, well-drained acid, neutral, and basic alkaline ( $\mathrm{pH}$ of 4.5-7.8.) soils (Marta, 2005; Vogel et al., 2002) and has an annual water requirement of 500 to $1,300 \mathrm{~mm}$.

The lemon-scented essential oil from the Lemon verbena have been widely studied for its calming, digestive, abdominal-discomfort, lemony flavor properties (Marta, 2005; Vogel et al., 2002; Argyropouloua et al., 2007).

Lemon verbena traditionally has been utilized as a remedy for gastrointestinal and respiratory disorders. In addition, some species have shown antimalarial, antiviral, anti-spasmodic, antibacterial, antioxidant and cytostatic properties (Ragone et al., 2007; Bilia et al., 2008; Funes et al., 2009; Regnier and Combrinck, 2010). The volatile oil yield oil yield (Martvnez et al., 2007; Ragone et al., 2007). Fresh or dried leaves are used in the same way as lemongrass as an ingredient in stews and soups (van Wyk, 2005). Evidence has shown that essential oil and phenolic compounds such as flavonoids are responsible for the related curative properties of lemon verbena (Rosa and Meireles, 2005). Lemon verbenas' essential oil obtained by hydrodistillation of the leaves is $0.22-1.00 \%$. The harvesting season, the time of the day, and the particle size present influence on the volatile (Martvnez et al., 2007).

According to the literature more attention is paid in Greece to the Lemon verbena essential oil while their effects on the parameters influencing multiple aspects of ecosystem structure (e.g. biodiversity, soil properties etc) are generally overlooked. Hence, this exploratory study aims to evaluate the effects of Lemon 
verbena and neighboring abandoned (10 years) ecosystems on the herbaceous plant species richness and composition, and soil properties.

\section{MATERIAL AND METHODS}

A number of field experiments were conducted in Thessaly plain (Experimental Farm of the University of Thessaly, Velestino, central Greece, 2014) with an altitude $170 \mathrm{~m}$ above the sea level (Fig.1). The soil at the site was a deep, moderately fertile, clay loamy soil that was classified as Calcixerollic Xerochrept (USDA, 1975).

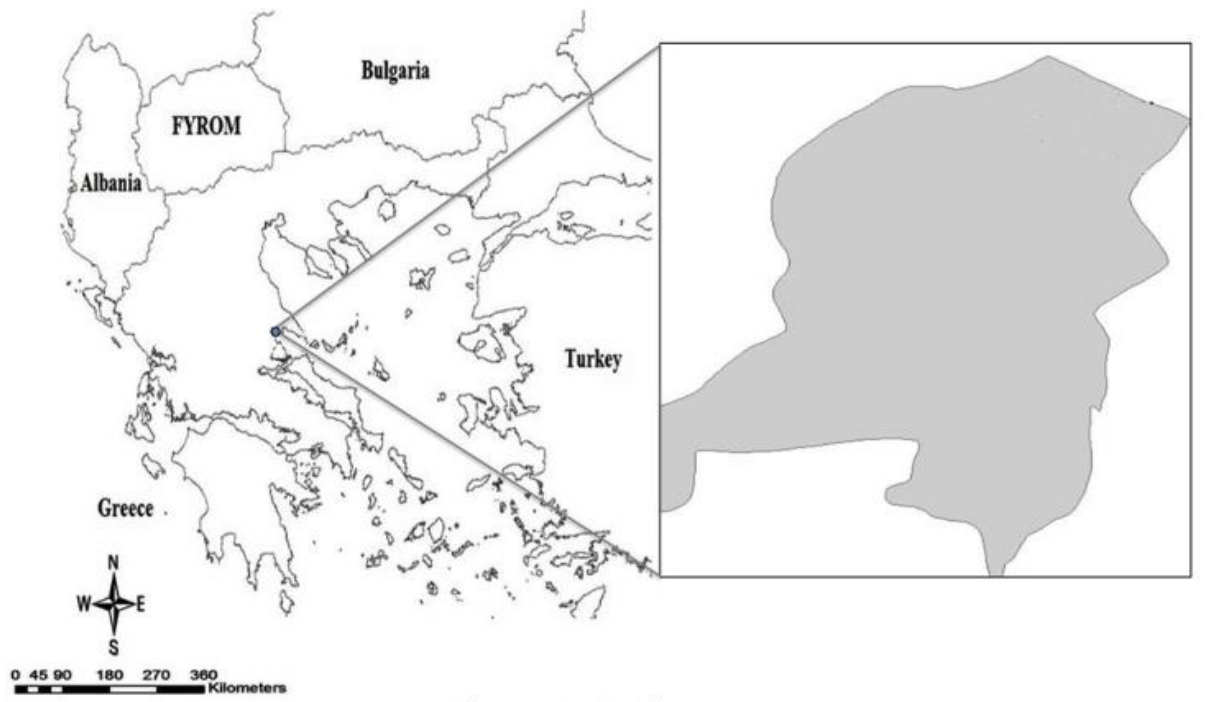

Figure 1. Study area

The climate in Greece is typical Mediterranean climate: mild and rainy winters, relatively warm and dry summers.

Thessaly Prefecture, the largest Greek lowland and the center of the country's agricultural production, is characterized by a more continental climatic character with colder winters and hot summers (Figure 2).

\section{Sampling}

The sampling of herbaceous plants was carried out in April-May 2016 and 2017 of central Greece in randomly selected plots of $0.25 \mathrm{~m}^{2}$, in order to record plant species richness in Lemon verbena ecosystem (Cook and Stubbendieck, 1986; Solomou and Sfougaris, 2013). In each plot composite soil samples were taken by the randomized method at a depth of $0-40 \mathrm{~cm}$. Soil organic matter $(\%)$ (Nelson and Sommers, 1982), pH (McLean, 1982), CaCO3 (Nelson and Sommers, 1982), texture (clay, silt, sand) (Bouyoukos, 1951), P (Olsen and Sommers, 1982), K and Mg (Thomas, 1982) were measured in each of the soil samples. 


\section{Statistical analysis}

Relation between plant species richness with soil characteristics was investigated by multivariate analysis. We used the 'multi-regression enter' method that suitable for quantity variables such as species richness (Kalantari, 2002) as a result to create a model. Statistical analyses were performed using the software package IBM SPSS Statistics ver. 19.0 for Windows (SPSS Inc., IBM Company, Chicago, IL, USA 2010).

\section{Velestino 2016-2017}

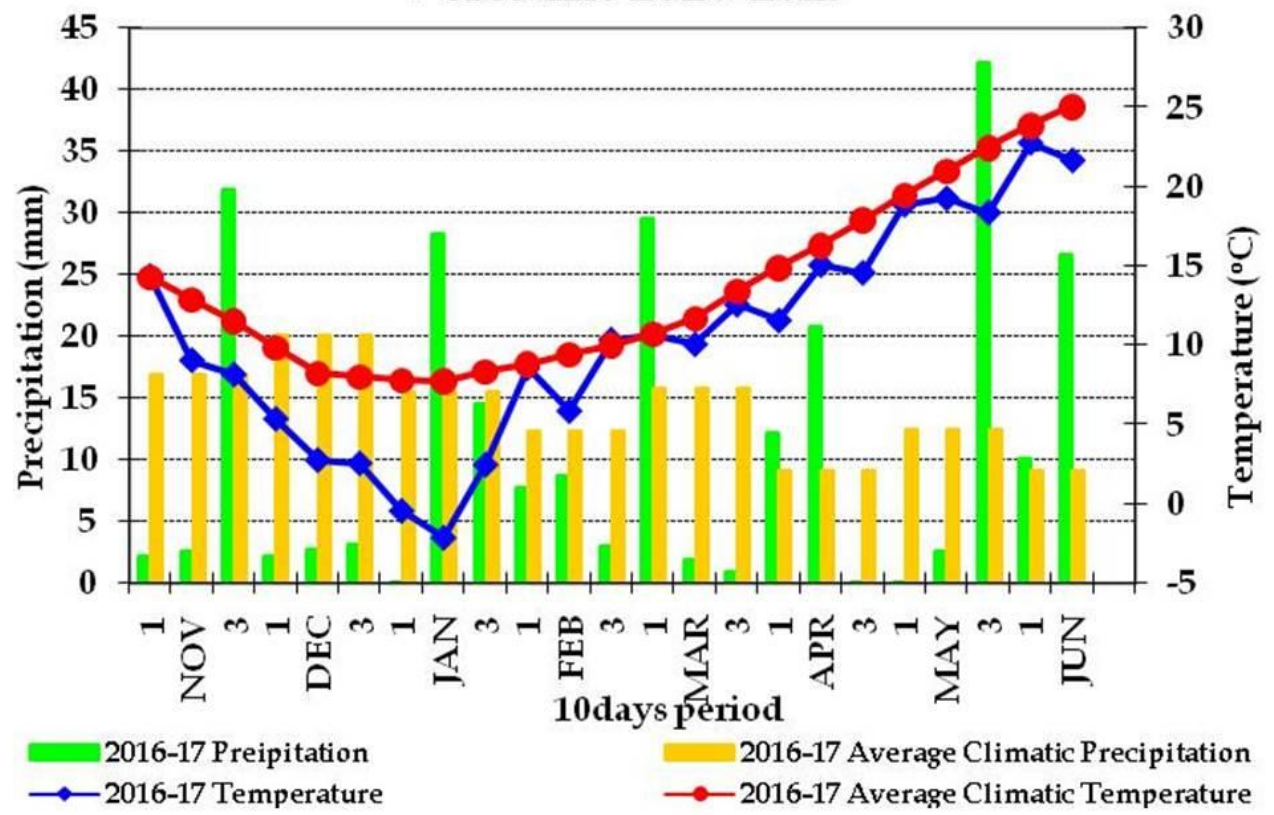

Figure 2. Climate diagram.

\section{RESULTS AND DISCUSSION}

Results showed that 24 species of herbaceous plants (16 plant species in Lemon verbena ecosystem and 12 plant species in abandoned ecosystem) were recorded in the study area. The most frequently occurring plant species was Avena sterilis (Family: Poaceae) in both types of ecosystems. A possible explanation is that this plant has transferred with seed and dispersal from another areas. Avena sterilis is highly invasive in cultivated farms and has probably already invaded many suitable regions of the Greece (Figure 3). According to Cirujeda et al. (2011) management practices, geographical gradients and climatic factors have been found to be the most important factors that explain herbaceous plant species composition and richness. 


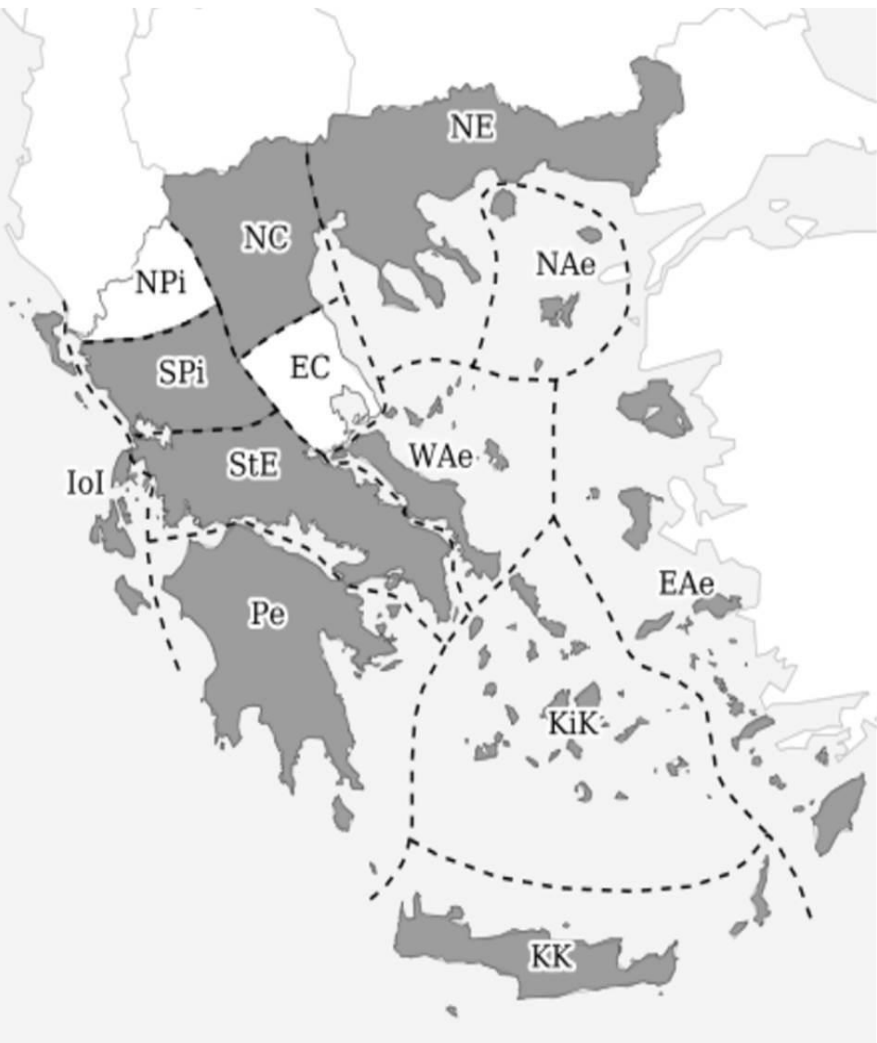

Figure 3. Distribution of Avena sterilis [Geography: IoI (Ionian Islands)-NPi (North Pindos) SPi (Souh Pindos) Pe (Peloponnisos) StE (Sterea Ellas)-EC (East Central Greece) NC (North Central Greece) NE (North-East Greece) NAe (North Aegean islands) WAe (West Aegean islands) Kik (Kiklades) KK (Kriti and Karpathos) EAe (Kriti and Karpathos). Greece: (East Aegean islands present; East Central Greece - absent; Ionian Islands - present; Kiklades present; Kriti and Karpathos - present; North Aegean islands - present; North Central Greece - present; North Pindos - absent; North-EastGreece - present; Peloponnisos - present; SouthPindos - present; Sterea Ellas - present; West Aegean islands - present)].

Generalized Linear Models (GLM) that came up from the processing of plant species richness data, only, in Lemon verbena ecosystem, showed good to excellent ability to "interpret" the dependent variable (herbaceous plant species richness) (based on adj. $\mathrm{R}^{2}$ ). The model showed that soil properties had significant effects on herbaceous plant species richness and interprets $78 \%$ of the total variation of herbaceous plant species richness. More specifically, soil organic matter, $\mathrm{pH}, \mathrm{P}$ and $\mathrm{K}$ were the most prominent factors influencing species richness in Lemon verbena ecosystem (Table 1). 
Table 1. Generalized Linear Model of herbaceous plant species richness.

\begin{tabular}{|c|c|c|c|c|c|}
\hline F & Adj. $\mathbf{R}$ & $\begin{array}{c}\text { Likelihood } \\
\text { Ratio } \chi^{2}\end{array}$ & AIC & P & Model \\
\hline 11,26 & 0,78 & 18,89 & 40,42 & 0,00 & $1,66+16,46(\mathrm{SOM})^{*}+0,02(\mathrm{SPH})^{* *}$ \\
\hline
\end{tabular}

"SOM: Soil organic matter, ${ }^{* *} \mathrm{SPH}$ : Soil $\mathrm{pH},{ }^{* * * *} \mathrm{P}$ : Phosphorus, ${ }^{* * * * *} \mathrm{~K}$ : Potassium.

It is known that ecosystems with different soil nutrients are important for plant growth and community development. Soil parameters like soil organic matter are related to plant species richness. The reason soil organic matter reflects changes in plant species richness is because there is a close relationship between soil organic matter content and plants. Crow (2009) refers that soil organic matter improves the capacity of a soil to hold water and nutrients, and allows their slow release, therefore improving the conditions for plant growth. Also, in sustainable management ecosystems (e.g. natural ecosystem), plant litter and roots are the origin of soil organic matter and higher plant diversity may lead to higher litter diversity, which in turn supports a greater diversity of decomposers and detritivores (Hansen, 2000) that increase soil organic matter content. Our result showed similarity with the study of Grime (1979), where species richness increases linearly with increase in soil $\mathrm{pH}$.

It is noteworthy that soil $\mathrm{P}$ and $\mathrm{K}$ are very important to plant functions and species richness. The direct effects of $\mathrm{P}$ and $\mathrm{K}$ on plant species richness probably is due to the application of fertilizers and intensity of land use, as a result in the uptake and storage of (added) nutrients in plants (Grime, 1979; Hautier et al., 2009).

Several studies have found correlations between changes in species richness and a gradient of nutrient availability (e.g. Huston 1980; Tilman 1982). According to a 'humped-back curve' (Grime, 1979; Tilman, 1982) species richness is low at low nutrient levels, increases to a peak at intermediate levels and declines more gradually at high nutrient levels. Similar results have been observed in a several studies (e.g. Tilman, 1982; Vermeer \& Berendse, 1983; Janssens et al.,1998; Lichter, 1999).

\section{CONCLUSIONS}

Lemon verbena is an ecosystem with very high importance value. A key finding in this study is that Lemon verbena ecosystem favors herbaceous plant species richness. Also, soil parameters such as soil organic matter, $\mathrm{pH}, \mathrm{P}$ and $\mathrm{K}$ were the most prominent factors influencing species richness in Lemon verbena ecosystem. The higher the species richness of an ecosystem, the higher the probability of maintaining ecosystem functions. Management plans for the biodiversity conservation of aromatic plant ecosystems should therefore focus on the specific site conditions and should take several abiotic and biotic factors into account. Hence, this study will continue into the future. 


\section{REFERENCES}

Argyropouloua C., Dafererab D., Tarantilisb P., Fasseasa C., Polissioub M., (2007). Chemical composition of the essential oil from leaves of (LippiaCitriodora $\mathrm{H}$. B. K.) (Verbenaceae) at two developmental stages. J. Biochem. System. Ecol. 35: 831-837.

Bilia A.R., Giomi M., Innocenti M., Gallori S., Vincieri F.F. (2008). HPLC-DADESI-MS analysis of the constituents of aqueous preparations of verbena and lemon verbena and evaluation of the antioxidant activity. J. Pharmaceut. Biomed. 46:463.

Bouyoukos G.J. (1951). A recalibration of the hydrometer method for making mechanical analysis of soils. Agronomy Journal 43:344-438

Cirujeda A., Aibar J., Zaragoza C. (2011). Remarkable changes of weed species in Spanish cereal fields from 1976 to 2007. Agronomy Sust. Developm. 31:675688.

Crow W. T. (2009). "Organic Matter, Green Manures and Cover Crops For Nematode Management." University of Florida. The Institute of Food and Agricultural Sciences.

Duarte C., Leme E., Delarmelina C., Soares A., Figueira G., Sartorato A. (2007). Activity of Essential Oils from Brazilian Medicinal Plants on Escherichia col.' J. Ethnol. Pharmacol. 111:197-201.

Funes L., Fernandez-Arroyo S., Laporta O., Pons A., Roche E., Segura-Carretero A., Fernandez-Gutiurrez A., Micol V. (2009). Correlation between plasma antioxidant capacity and verbascoside levels in rats after oral administration of lemon verbena extract. Food Chem. 117:589.

Grime J.P. (1979). The humped-back model: a response to Oksanen. Journal of Ecology 85: 97-98.

Hansen, R. A. (2000). Effects of habitat complexity and composition on a diverse litter microarthropod assemblage. Ecology 81:1120-1132.

Hautier Y., Niklaus P. A., Hector A. (2009). Competition for light causes plant biodiversity loss after eutrophication. - Science 324: 636-638.

Huston M.A. (1980). Soil nutrients and tree species richness in Costa Rican forests. J. Biogeogr. 7: 147-157.

Janssens F., Peeters A., Tallowin J.R.B., Bakker J.P., Bekker R.M., Fillat F., Oomes M.J.M. (1998). Relationship between soil chemical factors and grassland diversity. Plant Soil 202: 69-78.

Kalantari K. (2002). Data processing and analysis in socioeconomic research. Sharif Publication 38.

Lichter J. (1999). Primary succession and forest development on coastal lake Michigan sand dunes. Ecol. Monogr. 68: 487-510.

Marta C. (2005). Anti-candida activity of Brazilian medicinal plants. J. Ethnoph. 97:305-311.

Martvnez J., Rosa P.T.V., Meireles M.A.A. (2007). Extraction of clove and vetiver oils with supercritical carbon dioxide: Modeling and simulation. Open Chem. Eng. 1:1.

McLean E.O. (1982). Soil pH and lime requirement. In Methods of soil analysis: Chemical and microbiological properties, ed. A. L. Page, R. M. Miller, and D. 
R. Keeney, 199-224. Madison, Wisc.: Agronomy Society of America, Soil Science Society of America.

Nelson D.W., Sommers L.E. (1982). Total carbon, organic carbon, and organic matter. In Methods of soil analysis, part 2: Chemical and microbiological properties, ed. A. L. Page, 539-579. Madison, Wisc.: Agronomy Society of America and Soil Science Society of America.

Olsen S.R., Sommers L.E. (1982). Phosphorus. In Methods of soil analysis, part 2: Chemical and microbial properties, ed. A. L. Page, R. M. Miller, and D. R. Keeney. Madison, Wisc.: Agronomy Society of America and Soil Science Society of America.

Ragone M.I., Sella M., Conforti P.,Volonti M.G., Consolini A.E. (2007). The spasmolytic effect of Aloysiacitriodora, Palau (South American cedron) is partially due to its vitexin but not isovitexin on rat duodenums. J. Ethnopharmacol. 113:258.

Regnier T., Combrinck S. (2010). In vitro and in vivo screening of essential oils for the control of wet bubble disease of Agaricusbisporus. S. Afr. J Bot. 76:681.

Rosa P.T.V., Meireles M.A.M. (2005). Rapid estimation of the manufacturing cost of extracts obtained by supercritical fluid extraction. J. Food Eng. 67:235.

Solomou A., Martinos K., Skoufogianni E., Danalatos N. G. 2016. Medicinal and Aromatic Plants Diversity in Greece and Their Future Prospects: A Review. Agricultural Science 4: 9-20.

Thomas G.W. (1982). Exchangeable cations. In Methods of soil analysis, part 2: Chemical and microbiological properties, 2nd ed., ed. A. L. Page, R. M. Miller, and D. R. Keeney, 159-165. Madison, Wisc.: Agronomy Society of America, Soil Science Society of America.

Tilman D. (1982). Resource competition and community structure. Princeton University Press, Princeton, NJ.

van Wyk B.E. (2005). Food Plants of the World - Identification, Culinary Uses and Nutritional Value. Briza, Pretoria.

Vermeer J.G., Berendse F. (1983). The relationship between nutrient availability, shoot biomass and species richness in grassland and wetland communities. Vegetatio 53: 121- 126.

Vogel H., Silvaand M. 1., Razmilic I. (2002). Seasonal fluctuation of essential oil content in lemon verbena (aloysiatriphylla) ishsacta horticulture. Retrieved from www.actahort.org.

Zamorano-Ponce E., Fernandez J., Vargas G., Rivera P., Carballo M.A. (2004). Protective activity of cedron (Aloysiatriphylla) infusion over genetic damage induced by cisplatin evaluated by the comet assay technique. Toxicology Letters 152:85. 